Reprod. Nutr. Dévelop., 1981, 21 (3), 355-370.

\title{
Digestive enzymes in the germ-free animal
}

\author{
par T. CORRING, Catherine JUSTE, C. SIMOES-NUNES
}

Laborotoire de Physiologie de la Nutrition, INRA, 78350 jouy en Josas, France.

Summary. The digestive physiology of the germ-free animal has a number of characteristics (cecal hypertrophy, slower small intestine cell renewal, slower gastric emptying and intestinal transit) which distinguish it from that of the conventional animal. If the germ-free model is to be used to determine the role of gastrointestinal microflora in the nutrition of the conventional animal, it is essential to complete the study of these characteristics by data on digestive enzymes in the germ-free. The present paper analyzes these data.

There is little information on salivary amylase and none on gastric proteolytic enzymes and intestinal peptidases. More complete data on exocrine pancreas enzymes and intestinal disaccharidases show that the digestive equipment is similar in germ-free and conventional animals. Bile salts, not considered as digestive enzymes, are qualitatively and quantitatively different, depending on the digestive tract bacterial environment.

In general, the germ-free animal has some characteristics which should permit better utilization of the diet ingested. Measurements of apparent digestibility do not confirm this hypothesis since results obtained in germ-free and conventional animals of the same species are contradictory.

The germ-free animal is certainly a very useful tool for studying the role of gastrointestinal microflora in the nutrition of its host. The large intestine contains the largest bacterial population (1 to $3.10^{10}$ bacteria $/ g$ fresh contents) and the greatest number of microbial species in the gut (Ducluzeau and Raibaud, 1975 ; Schaedler, 1973). In some cases, bacteria may efficiently intervene in the digestive utilization of the dief ingested by the animal (Rérat, 1978).

However, a number of experiments in the germ-free animal have shown that it cannot be considered simply as a conventional animal, deprived of gastrointestinal microflora, since certain characteristics of its digestive physiology distinguish it from the conventional animal (see reviews by Gordon et al., 1966 ; Combe ef al., 1976). A knowledge of these characteristics is essential when determining the part due to bacteria in the digestion of an ingested diet.

The germ-free state in rodents and lagormorphs leads to a substantial increase in cecal sac contents and size (Glimstedt, 1936 ; Wostmann and Bruckner-Kardoss, 1959 ; Wostmann, Bruckner-Kardoss and Knight, 1968 ; Pleasants, 1959). The same observation was made in the rat (Lee and Moinuddin, 1958), mouse (Meynell, 1963) and guinea-pig (Jervis and Biggers, 1964) after antibiotic treatment. 
The morphology of the small intestine in the germ-free rat (Gordon and Wostmann, 1960), guinea-pig (Sprinz et al., 1961) and chicken (Thorbecke et al., 1957) differs by a lower weight, a smoother mucosa and a smaller reticulo-endothelial cell population. The small intestine mucosal surface area of the germ-free rat is on an average 30 p. 100 lower than that of the conventional animal ; this reduction is marked in the mid and lower parts of the small intestine and relatively slight in the upper segments (Gordon and Bruckner-Kardoss, 1961). But, according to Meslin (1971), the mucosal surface area of the proximal intestine is larger and that of the distal part more reduced in the germ-free than in the conventional rat. After deduction of cecal content weight, there was no difference between germ-free and conventional rats when considering the total surface of the intestinal mucosa relative to body weight (Meslin, Sacquet and Guenet, 1973).

Some differences between germ-free and conventional states were also emphasized in the epithelial renewal rate of the small intestine. The transit time of cells moving from the crypts to the villus tips is twice as long in the ileum of the germ-free mouse as in that of its conventional counterpart and depends on cell production which, in turn, is related to the number of cells in the proliferative pool and the duration of the generative cycle (Abrams, Baver and Sprinz, 1963). The generative cycle time for duodenal crypt cells is longer in the germ-free than in the conventional mouse $(13.6 \mathrm{~h}$ vs $11.2 \mathrm{~h})$; in the former, the generation rate of proliferative cells is reduced by 20 p. 100 and the size of the proliferative cell population is decreased by about 37 p. 100 (Lesher, Walburg and Sacher, 1964).

The transit rate of the intestinal cells in the germ-free rat is reduced by about 30 p. 100 and the mitotic index of the Lieberkühn crypts is lower (Guenet et al., 1970). In the chicken, the rate of epithelial cell migration is lower in the germ-free than in the conventional state, but the relative differences are greater in the lower than in the upper intestine (Rolls, Turvey and Coates, 1978).

Gastric emptying and small intestinal transit of the ingested food were found to be slower in the germ-free than in the conventional state. Six hours after a labelled test-meal, the cecum of the germ-free mouse retained a greater percentage of radioactivity than the cecum of the conventional animal, and the passage of the marker into the feces was slower (Abrams and Bishop, 1967). Gastrointestinal transit was also slower in the germ-free than in the conventional rat (Sacquet, Garnier and Raibaud, 1970 ; Riottot ef al., 1980), and tended to be longer in germ-free rats fed irradiated diets than in those fed autoclaved diets (Riottot et al., 1980).

The aim of the present review is to complete our knowledge of the characteristics of germ-free animal digestive physiology by analyzing data on digestive enzymes. These enzymes (proteolytic enzymes acting on proteins, glycolytic enzymes on carbohydrates and lipolytic enzymes on lipids) will be discussed in order according to the nature of the dietary substrate they hydrolyze.

\section{Proteolytic enzymes}

The first step in the enzymatic hydrolysis of dietary proteins occurs in the gastric lumen under the action of pepsins and $\mathrm{HCl}$ (Seijffers, Segal and Miller, 1963). Hydro- 
lysis then continues in the intestine where proteins and peptides from gastric hydrolysis are submitted to the action of pancreatic proteolytic enzymes and intestinal peptidases (Gray and Cooper, 1971 ; Heizer, Kerley and Isselbacher, 1972).

Gastric enzymes. - Proteolytic enzyme hydrolysis in the stomach is mainly performed by the pepsins secreted in an inactive form (pepsinogens) and activated by $\mathrm{HCl}$. To our knowledge, no data are available on pepsinogen biosynthesis and secretion in germ-free animals. Rozé ef al. (1977) reported that basic $\mathrm{HCl}$ secretion was higher (X 2.7) in the germ-free than in the conventional rat and that basal gastrinemia in these animals was not different.

The stomach of the germ-free guinea-pig has the same aspect as that of the conventional animal (Philips, Wolfe and Gordon, 1959), and there is no histological difference in the gastric mucosae of germ-free and conventional mice (Savage, Schaedler and Dubos, 1967). However, these results were obtained in experiments dealing with a microscopic study of gland anatomy, and they do not provide any information on the cellular aspect in either environment.

Pancreatic enzymes. - Pancreatic proteolytic enzymes (chymotrypsinogen, trypsinogen, procarboxypeptidases $A$ and $B$, proelastase) are secreted, in a inactive form, by the exocrine pancreatic cells and are activated in the intestinal lumen by enterokinase, an intestinal enzyme.

The tissue levels of chymotrypsinogen and trypsinogen appear to be similar in both germ-free and conventional states (table 1) in the chicken (Coates, Hewitt and Golob, 1970) and the rat (Lepkovsky ef al., 1966 ; Reddy, Pleasants and Wostmann, 1969).

\section{TABLE 1}

Proteolytic activities in the pancreas and in small infestine confents of germ-free (GF) and conventional (CV) animals

\begin{tabular}{|c|c|c|c|c|c|c|}
\hline & \multirow[t]{2}{*}{ Species } & \multicolumn{2}{|c|}{ Pancreas } & \multicolumn{2}{|c|}{$\begin{array}{l}\text { Small intestine } \\
\text { contents }\end{array}$} & \multirow[t]{2}{*}{ Reference } \\
\hline & & GF & CV & GF & CV & \\
\hline \multirow[t]{2}{*}{ Protease } & chicken .......... & - & - & 1.43 & 1.73 & 1 \\
\hline & rat $\ldots \ldots \ldots \ldots \ldots$ & 6.21 & 4.76 & 1.79 & 1.96 & 2 \\
\hline \multirow[t]{4}{*}{ Trypsin } & chicken $(a) \ldots \ldots \ldots$ & - & - & 74.5 & 80 & 1 \\
\hline & chicken $(a) \ldots \ldots \ldots$ & 18.2 & 16.6 & - & 一 & 3 \\
\hline & rat $\left({ }^{a}\right) \ldots \ldots \ldots \ldots \ldots$ & 78 & 79.6 & 78.3 & 74.8 & 2 \\
\hline & $\begin{array}{l}\text { rat }(a) \ldots \cdots \cdots \cdots \cdots \\
\text { rabbit. } \ldots \ldots \ldots \ldots \cdots\end{array}$ & & $\stackrel{749}{-}$ & $\begin{array}{l}308 \\
219.2\end{array}$ & $\begin{array}{l}205 \\
198.2\end{array}$ & $\begin{array}{l}4 \\
5\end{array}$ \\
\hline Chymotrypsin & $\begin{array}{l}\text { rat } \ldots \ldots \ldots \ldots \ldots \ldots \\
\text { rabbit } \ldots \ldots \ldots \ldots \ldots\end{array}$ & 896 & 913 & $\begin{array}{l}480 \\
160.2\end{array}$ & $\begin{array}{l}246 \\
100\end{array}$ & $\begin{array}{l}4 \\
5\end{array}$ \\
\hline
\end{tabular}

1. Lepkovsky ef al. (1964), meq tyrosine released in $10 \mathrm{~min} / \mathrm{g}$ dry solids. ( ${ }^{a}$ ) In percentage of total proteolytic activity.

2. Lepkorsky et al. (1966), idem.

3. Coafes, Hewitt and Golob (1970), change in 1.0 optical density/min.

4. Reddy, Pleasants and Wostmann (1969), trypsin : $\mu$ moles TAME and chymotrypsin : $\mu$ moles BTEE, hydrolyzed $/ \mathrm{min}$ and $/ 100 \mathrm{~g}$ body weight (pancreas) or $/ \mathrm{g}$ intestine contents.

5. Malis ef al. (1976), $\mu \mathrm{g}$ trypsin and $\mu \mathrm{g}$ chymotrypsin $/ g$ intestine contents. 
In addition, there is no difference between the germ-free and conventional chicken (Lepkovsky et al., 1964) and rat (Lepkovsky et al., 1966 ; Reddy, Pleasants and Wostmann, 1969 ; Genell, Gustafsson and Ohlsson, 1976) as regards pancreatic proteolytic activity in the small intestine contents (table 1). According to Malis ef al. $(1974,1976)$, chymotrypsin activity is higher in the ileal contents of the germ-free than of the conventional rabbit (table 1).

According to Borgström et al. (1959) and Loesche (1968), pancreatic proteolytic enzymes are largely inactivated by the intestinal microflora in the distal part of the digestive tract. The concentrations of pancreatic proteases are lower in the cecal contents of the conventional chicken (Lepkovsky et al., 1964), rat (Loesche, 1968 ; Reddy, Pleasants and Wostmann, 1969), mouse (Loesche, 1968) and rabbit (Malis ef al., 1974, 1976) than in those of their germ-free counterparts (table 2). Chymotrypsin and elastase activities appear to be more sensitive to bacterial inactivation than is trypsin activity (Malis et al., 1976 ; Genell, Gustafsson and Ohlsson, 1976).

TABLE 2

Proteolytic activities in the cecum contents and feces of germ-free (GF) and conventional (CV) animals

\begin{tabular}{|c|c|c|c|c|c|c|}
\hline & \multirow[t]{2}{*}{ Species } & \multicolumn{2}{|c|}{ Cecum contents } & \multicolumn{2}{|c|}{ Feces } & \multirow[t]{2}{*}{ Reference } \\
\hline & & GF & $\mathrm{CV}$ & GF & $\mathrm{CV}$ & \\
\hline \multirow[t]{2}{*}{ Protease } & $\ldots \ldots \ldots \ldots$ & 1.48 & 0.23 & - & - & 1 \\
\hline & rat $\ldots \ldots \ldots \ldots \ldots \ldots$ & 1.15 & 0.77 & - & - & 2 \\
\hline \multirow[t]{6}{*}{ Trypsin } & chicken $(a) \ldots \ldots \ldots \ldots \ldots$ & 80 & 62.5 & - & - & 1 \\
\hline & rat $\ldots \ldots \ldots \ldots \ldots \ldots \ldots$ & - & - & 1.6 & 0 & 6 \\
\hline & $\operatorname{rat}(a) \ldots \ldots \ldots \ldots \ldots \ldots$ & 80.9 & $\begin{array}{r}76.1 \\
51\end{array}$ & - & - & $\frac{2}{7}$ \\
\hline & rat $(a) \ldots \ldots \ldots \ldots \ldots \ldots \ldots \ldots$ & $\begin{array}{l}72.2 \\
298\end{array}$ & $\begin{array}{r}3.1 \\
18.1\end{array}$ & - & - & 4 \\
\hline & rabbit $\ldots \ldots \ldots \ldots \ldots \ldots$ & 210.6 & 158.3 & - & 一 & 5 \\
\hline & mouse $\ldots \ldots \ldots \ldots \ldots$ & 64.1 & 1.5 & 一 & - & 7 \\
\hline \multirow[t]{4}{*}{ Chymotrypsin } & rat $\ldots \ldots \ldots \ldots \ldots \ldots$ & 133 & 8.53 & - & - & 4 \\
\hline & rat $\ldots \ldots \ldots \ldots \ldots \ldots$ & 55.8 & 1.6 & - & 一 & 7 \\
\hline & rabbit $\ldots \ldots \ldots \ldots \ldots \ldots$ & 118.2 & 85.2 & - & - & 5 \\
\hline & mouse $\ldots \ldots \ldots \ldots \ldots$ & 25.2 & 1.5 & 一 & - & 7 \\
\hline
\end{tabular}

$1,2,3,4$ and 5 , see table 1 .

6. Borgström et al. (1959), mg trypsin.

7. Loesche (1968), trypsin and chymotrypsin spectrophotometrically determined after hydrolysis of BAEE and ATEE, respectively, and compared to standard amounts of trypsin and chymotrypsin.

Moreover, data obtained by Genell, Gustafsson and Ohlsson (1976) do not indicate any enzyme reabsorption in the large intestine of the germ-free animal since both trypsin and elastase appeared in the feces in the same concentrations as in the cecal contents.

The absence of microflora in the rat does not cause any modifications in pancreatic weight or histological structure (Reddy, Pleasants and Wostmann, 1969). The atrophy and fibrotic changes observed in the germ-free rat by Geever, Daft and Levenson (1965) might be explained by the presence of tween 80 and deficiency or lack of 
selenium and chromium in the diet used by the authors (Reddy, Pleasants and Wostmann, 1969). In addition, the trypsic inhibitor in the diet induced the same pancreatic weight increase in the chicken (Coates, Hewitt and Golob, 1970) and the rat (Kwong et al., 1971), whatever the bacterial environment. To our knowledge, no data are available on intestinal peptidases in the germ-free animal.

\section{Glycolytic enzymes}

Dietary carbohydrates are hydrolyzed by salivary and mainly pancreatic amylases ; in the intestinal mucosa, they are hydrolyzed by disaccharidases. It must be recalled that there is no cellulase in the intestine of germ-free animals, this enzyme being of bacterial origin.

Salivary amylase. - Data on this enzyme are scarce. Szylit (1973) and IvorecSzylit, Raibaud and Schellenberg (1973) showed the existence of an amylase in the crop of germ-free fowl. The action of the enzyme may be understood by some studies showing that heated starches are completely degraded in the germ-free animal before reaching the duodenum (chicken : Masson, 1954 ; Bewa, Charlet-Lery and Szylit, 1979 ; other monogastric species : Baker ef al., 1950).

Pancreatic amylase. - There is no difference in the level of pancreatic tissue amylase activity (table 3) in germ-free and conventional rats (Lepkovsky et al., 1966 ; Reddy, Pleasants and Wostmann, 1969) and chickens (Coates, Hewitt and Golob, 1970). According to Reddy, Pleasants and Wostmann (1969) studying the rat, Lepkovsky ef al. (1964) the chicken, and Yoshida ef al. (1968) the rabbit, pancreatic amylase is partially inactivated in the distal part of the digestive tract in the conventional animal (table 3). On the contrary, Lepkovsky et al. (1966) found a higher enzyme activily in

\section{TABLE 3}

Amylase activity in the pancreas, small intestine, cecum contents and feces of germ-free (GF) and conventional (CV) animals

\begin{tabular}{|c|c|c|c|c|c|c|c|c|c|}
\hline \multirow[t]{2}{*}{ Species } & \multicolumn{2}{|c|}{ Pancreas } & \multicolumn{2}{|c|}{$\begin{array}{l}\text { Small intestine } \\
\text { contents }\end{array}$} & \multicolumn{2}{|c|}{ Cecum contents } & \multicolumn{2}{|c|}{ Feces } & \multirow[t]{2}{*}{ Reference } \\
\hline & GF & $\mathrm{CV}$ & GF & $\mathrm{CV}$ & GF & $\mathrm{CV}$ & GF & $\mathrm{CV}$ & \\
\hline Rat $\ldots$. & - & - & - & - & - & 一 & $100-160$ & $40-100$ & 1 \\
\hline Rat $\ldots$. & 630 & 567 & 119 & 113 & 2.2 & 9.7 & - & - & 3 \\
\hline Rat .... & 1374 & 1545 & 616 & 333 & 70.9 & 2.4 & - & - & 4 \\
\hline Chicken. & - & - & 90 & 104 & 9.0 & 4.5 & - & - & 2 \\
\hline Chicken. & 280 & 281 & - & - & - & - & - & 一 & 5 \\
\hline Rabbit .. & - & - & 8.37 & 7.37 & 2.55 & 0.60 & - & - & 6 \\
\hline
\end{tabular}

1. Borgström et al. (1959), $\mathrm{mg}$ maltose released in $3 \mathrm{~min}$.

2. Lepkovsky ef al. (1964), $\mathrm{mg}$ starch hydrolyzed in $15 \mathrm{~min} \times 10^{3} / \mathrm{g} \mathrm{dry}$ solids.

3. Lepkovsky et al. (1966), idem.

4. Reddy, Pleasants and Wostmann (1969), umoles $\times 10^{-3}$ maltose released $/ \mathrm{min} / 100 \mathrm{~g}$ body weight (pancreas) or $/ g$ contents.

5. Coates, Hewitt and Golob (1970), g starch hydrolyzed/h.

6. Yoshida ef al. (1968), $\mu$ moles maltose released $/ 30 \mathrm{~min} / \mathrm{mg}$ protein. 
the distal part of the intestine of the conventional rat, whereas Borgström et al. (1959) showed no difference between the fecal amylase activities of germ-free and conventional rats.

Intestinal disaccharidases. - The hydrolytic products, resulting from amylase action on dietary carbohydrates, are submitted to the action of different disaccharidases distributed along the small intestine. The disaccharidase distribution pattern is similar in germ-free and conventional rats (Dahlqvist, 1963 ; Dahlqvist and Thomson, 1964 ; Reddy and Wostmann, 1966), chickens (Siddons, 1969) and rabbits (Malis ef al., 1974). In addition, age changes in disaccharidase activities and the effect of diet on these activities are not influenced by the bacterial environment. Thus, the decrease in lactase and cellobiase and the increase in maltase, invertase and trehalase at weaning are similar in germ-free and conventional rats (Reddy and Wostmann, 1966). The microflora does not change disaccharidase adaptation to the dietary substrate in the rat (Reddy, Pleasants and Wostmann, 1968), and a mash diet, compared to a liquid diet, leads to the same stimulation of enzyme activities in both germ-free and conventional chickens, taking into account the different weight profile of the germfree animal (Siddons and Coates, 1972). The reduction of sucrase, maltase and lactase activities in the germ-free rat after 48-hr starvation is similar to that observed in the gnotobiotic animal (Ecknauer and Raffler, 1978). Moreover, Larner and Gillepsie (1957) and Reddy and Wostmann (1966) showed that enzyme biosynthesis is not affected by intestinal bacteria.

\section{TABLE 4}

Disaccharidase activities in the small intestine of germ-free (GF) and conventional (CV) animals

\begin{tabular}{|c|c|c|c|c|}
\hline Enzyme & Species & GF & $\mathrm{CV}$ & Reference \\
\hline Maltase & $\begin{array}{l}\text { rat } \ldots \ldots \ldots \ldots \ldots \ldots \\
\text { chicken }(a) \ldots \ldots \ldots \ldots \ldots \\
\text { rabbit } \ldots \ldots \ldots \ldots \ldots \ldots\end{array}$ & $\begin{array}{l}24.1 \\
83.6 \\
35.7\end{array}$ & $\begin{array}{r}9.6 \\
88.4 \\
16.4\end{array}$ & $\begin{array}{l}1 \\
2 \\
3\end{array}$ \\
\hline Sucrase & $\begin{array}{l}\text { rat } \ldots \ldots \ldots \ldots \ldots \ldots \ldots \\
\text { chicken }\left({ }^{a}\right) \ldots \ldots \ldots \ldots \ldots \ldots \\
\text { rabbit } \ldots \ldots \ldots \ldots \ldots \ldots\end{array}$ & $\begin{array}{r}3.2 \\
15.6 \\
9.5\end{array}$ & $\begin{array}{c}1.32 \\
16.9 \\
4.8\end{array}$ & $\begin{array}{l}1 \\
2 \\
3\end{array}$ \\
\hline Trehalase & 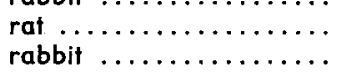 & $\begin{array}{l}5.1 \\
6.6\end{array}$ & $\begin{array}{l}1.7 \\
2.7\end{array}$ & $\begin{array}{l}1 \\
3\end{array}$ \\
\hline Cellobiase & $\underset{\text { rabbit } \ldots \ldots \ldots \ldots \ldots \ldots}{\text { rat }} \ldots \ldots \ldots \ldots$ & $\begin{array}{l}0.37 \\
0.22\end{array}$ & $\begin{array}{l}0.10 \\
0.07\end{array}$ & $\begin{array}{l}1 \\
3\end{array}$ \\
\hline $\begin{array}{l}\text { Palatinase } \\
\text { Lactase }\end{array}$ & $\begin{array}{l}\text { chicken }\left({ }^{a}\right) \ldots \ldots \ldots \ldots \ldots \\
\text { rat } \ldots \ldots \ldots \ldots \ldots \ldots \\
\text { chicken }\left({ }^{a}\right) \ldots \ldots \ldots \ldots \ldots \\
\text { rabbit } \ldots \ldots \ldots \ldots \ldots \ldots\end{array}$ & $\begin{array}{l}3.3 \\
1.2 \\
0.16 \\
0.46\end{array}$ & $\begin{array}{l}3.6 \\
0.31 \\
0.21 \\
0.19\end{array}$ & $\begin{array}{l}2 \\
1 \\
2 \\
3\end{array}$ \\
\hline
\end{tabular}

1. Reddy and Wostmann (1966), $\mu$ moles of disaccharide hydrolyzed/mg protein $/ 60 \mathrm{~min}$. weight.

2. Siddons and Coates (1972), $\mu$ moles of disaccharide hydrolyzed/60 min. (a) Total activity/body

3. Yoshida et al. (1968), $\mu$ moles of disaccharide hydrolyzed/mg protein/60 min.

The data on each of the enzyme activities in both germ-free and conventional states are contradictory. Maltase, sucrase, palatinase and lactase activities are similar 
in germ-free and conventional chickens (Siddons, 1969 ; Siddons and Coates, 1972) (table 4) ; about 97 p. 100 or more of this activity can be recorded in the intestinal wall. The germ-free rat exhibits the same glucosidase, maltase and sucrase activities as its conventional counterpart (Larner and Gillepsie, 1957 ; Dahlqvist, Bull and Gustafsson, 1965). In contrast, maltase, sucrase, trehalase, cellobiase and lactase activities are higher in the germ-free rat after weaning (table 4) (Reddy and Wostmann, 1966 ; Kawai and Morotomi, 1978). In the same species, Dahlqvist, Bull and Gustafsson (1965) only found higher activities for lactase and cellobiase in the germ-free animal. According to Yoshida ef al. (1968), maltase, sucrase, trehalase, lactase and cellobiase activities are higher in the small intestine mucosa of the germ-free than of the conventional rabbit (table 4). Maltase, sucrase and lactase activities are higher in the small intestine mucosa of the germ-free rat, whereas trehalase and cellobiase activities are the same as in the conventional animal (Reddy and Wostmann, 1966). According to the latter authors, the lower enzyme activity in conventional animals might be explained in two ways, if one considers that disaccharidases are located intracellularly and that their action cannot be exerted in the intestinal contents (Dahlqvist and Borgström, 1961). On the one hand, enzymes would be partially inactivated inside the mucosal cell by the bacterial products which enter the cell wall. On the other hand, the higher enzyme activity in the germ-free animal would reflect a more advanced mucosal cell maturity and thus a more elevated enzyme level. But this eventuality is not known in all species.

The desquamated cells lead to disaccharidase activity in the intestinal contents, and the question is to determine whether the number of these cells depends on the bacterial environment. According to Meslin, Sacquet and Raibaud (1974), the production of epithelial cells by cell column is the same in the duodenum and jejunum of germ-free and conventional rats but higher in the ileum of the conventional animals. Different authors agree that the enzyme level in the distal part of the digestive tract of the germ-free animal is higher due to bacterial inactivation of the enzymes in the conventional animal (Borgström et al., 1959 ; Dahlqvist, Bull and Gustafsson, 1965 ; Reddy and Wostmann, 1966 ; Kawai and Morotomi, 1978).

\section{Lipolytic enzymes}

Lipids are mainly hydrolyzed in the intestinal lumen through the action of pancreatic lipase. Lipolysis needs the presence of bile salts and colipase. The latter was only found recently (Maylie et al., 1971) and, while a few data are available on the conventional animal, they are completely lacking on the germ-free.

Pancreatic lipase. - There is no difference between the pancreatic tissue lipase levels in germ-free and conventional rats (Lepkovsky et al., 1966 ; Reddy, Pleasants and Wostmann, 1969) (table 5). In the small intestine contents of the rat, the same authors showed that lipase activity is not modified by the bacterial environment. In the cecum and colon of the rat, Reddy, Pleasants and Wostmann (1969) have reported that enzyme activity is significantly higher in the germ-free animal ; this disagrees with the results of Lepkovsky ef al. (1966) in the rat and of Lepkovsky et al. (1964) in the 
chicken, showing no difference in the distal part of the digestive tract, whatever the bacterial environment (table 5).

TABLE 5

Lipose activity in the pancreas, small infestine and cecum contents of germ-free (GF) and conventional (CV) animals

\begin{tabular}{|c|c|c|c|c|c|c|c|}
\hline \multirow[t]{2}{*}{ Species } & \multicolumn{2}{|c|}{ Pancreas } & \multicolumn{2}{|c|}{ Small infestine contents } & \multicolumn{2}{|c|}{ Cecum contents } & \multirow[t]{2}{*}{ Reference } \\
\hline & GF & $\mathrm{CV}$ & GF & $C V$ & GF & $C V$ & \\
\hline $\begin{array}{l}\text { Chicken } \ldots \ldots \\
\text { Rat } \ldots \ldots \ldots \\
\text { Rat } \ldots \ldots \ldots\end{array}$ & $\begin{array}{l}\overline{257} \\
493\end{array}$ & $\begin{array}{l}\overline{259} \\
599\end{array}$ & $\begin{array}{c}3.98 \\
14.6 \\
159\end{array}$ & $\begin{array}{c}4.40 \\
17.3 \\
143\end{array}$ & $\begin{array}{l}1.64 \\
5.1 \\
55.2\end{array}$ & $\begin{array}{l}2.51 \\
5.7 \\
2.1\end{array}$ & $\begin{array}{l}1 \\
2 \\
3\end{array}$ \\
\hline
\end{tabular}

1. Lepkovsky ef ol. (1964), meq. of fatty acids released in $20 \mathrm{~min} / \mathrm{g}$ of dry solids.

2. Lepkovsky ef al. (1966), idem.

3. Reddy, Pleasants and Wostmann (1969), micromoles of fatty acids released per min $/ 100 \mathrm{~g}$ body weight (pancreas) or $/ g$ contents.

According to Reddy, Pleasants and Wostmann (1969), the stability of pancreatic lipase is intermediate between that of pancreatic proteases and pancreatic amylase.

Bile salts. - The greatest number of studies in the germ-free animal concern bile and bile salts. In conventional animals, bile acids are excreted in a conjugated form in the intestinal lumen where they are submitted to microflora action. Bacterial hydrolases can split the bond between bile acid and taurine or glycine (Aries and Hill, 1970a) and bacterial dehydrogenases can either form ketones or reduce ketones to alcohols (Aries and Hill, 1970b). Cholic acid is transformed into deoxycholic acid and chenodeoxycholic acid into lithocholic acid under the action of bacterial $7 \alpha$-dehydroxylase (Aries and Hill, 1970b). This $7 \alpha$-dehydroxylase does not act on conjugated bile salts or on their methyl esters (Aries and Hill, 1970b). Some bacteria can form a $5 \alpha$-cholanic acid from bile acids with a ketone function in position 3 after induction of a double bond in position 4 (Aries and Hill, 1970c). Bile acids are reabsorbed via passive diffusion in all regions of the intestine and via active absorption in the ileum (Schiff, Small and Dietschy, 1972).

The absence of microflora in the germ-free leads to reabsorption of essentially primary bile salts, i.e. salts which have not been modified. In addition, the bile salt composition of the secreted bile is simpler than that of the conventional animal (Sacquet, 1971 ; Demarne, Sacquet and Garnier, 1972). In the germ-free rabbit (Hofmann, Mosbach and Sweeley, 1964), 95 p. 100 of the bile salts are constituted of cholic acid, whereas in its conventional counterpart, 95 p. 100 contain deoxycholic acid, reflecting the absence in the rabbit liver of any enzyme responsible for rehydroxylation of deoxycholic acid in position 7 . In the germ-free rat, about $98 \mathrm{p.} 100$ of the bile salts in the bile are cholic and $\beta$-muricholic acids (Wostmann, 1973), and hyodeoxycholic, deoxycholic and lithocholic acids are absent in that secretion (Demarne, Sacquet and Garnier, 1972). The conventional rat, fed raw potato starch or lactose, secreted bile acids qualitatively similar to those found in the germ-free animal, indicating that very little microbial dehydroxylation occurred with some diets (Kellogg, 1971). 
TABLE 6

Bile acids in small and large intestine and fecal excretion in germ-free (GF) and conventional (CV) animals

\begin{tabular}{|c|c|c|c|c|c|c|c|c|c|}
\hline \multirow[t]{2}{*}{ Species } & \multicolumn{2}{|c|}{$\begin{array}{c}\text { Small } \\
\text { intestine }\end{array}$} & \multicolumn{2}{|c|}{$\begin{array}{l}\text { Bladder and } \\
\text { small intestine }\end{array}$} & \multicolumn{2}{|c|}{$\begin{array}{l}\text { Cecum and } \\
\text { large intestine }\end{array}$} & \multicolumn{2}{|c|}{$\begin{array}{l}\text { Fecal } \\
\text { excretion }\end{array}$} & \multirow[t]{2}{*}{ Reference } \\
\hline & GF & $\mathrm{CV}$ & GF & $\mathrm{CV}$ & GF & $\mathrm{CV}$ & GF & $\mathrm{CV}$ & \\
\hline Rat ... & - & - & - & - & - & - & 11.3 & 21.4 & 1 \\
\hline Rat ... & 100.8 & 54.6 & - & - & 63 & 29.7 & 25.2 & 31.4 & 2 \\
\hline Mouse. & - & - & 211.3 & 115 & 30.3 & 12.4 & 29.3 & 41.2 & 3 \\
\hline
\end{tabular}

1. Kellogg and Wostmann (1969a), mg/kg body weight.

2. Sacquet ef al. (1975), umoles.

3. Eyssen, Parmentier and Mertens (1976), $\mathrm{mg} / \mathrm{kg}$ body weight.

The bile acid pool is larger and fecal bile acid excretion is lower in the germ-free rat (Kellogg and Wostmann, 1969a; Kellogg, 1971 ; Sacquet ef al., 1975) and the germ-free mouse (Eyssen, Parmentier and Mertens, 1976) (table 6). In the germ-free rat harbouring bacteria that reduce cecal distension but do not metabolize bile acids, the values of the intestinal pool and of fecal bile acid excretion are located between those of germ-free and conventional animals (Sacquet et al., 1976). According to Wostmann ef al. (1976), the addition of lactose to the diet results in different bile salt compositions in germ-free and conventional rats ; bile acid metabolism is not affected, contrary to data reported by Sacquet, Leprince and Riottot (1979). In addition, the latter authors and Riottot ef al. (1980) showed that the intestinal pool and fecal bile acid excretion mainly depend on small intestine transit time which is longer in the germ-free than in the conventional rat.

In the germ-free state, a higher intestinal bile acid pool would determine a greater bile acid flow through the liver, leading to a decrease in biosynthesis mediated by a feedback mechanism (Sacquet, Leprince and Riottot, 1979). Moreover, the more active enterohepatic circulation of bile salts in the germ-free animal leads to a decrease in the catabolism of hepatic cholesterol (Kellogg, 1971 ; Wostmann, 1973). Liver cholesterol concentrations are three times higher in the germ-free rat fed a purified diet containing 0.5 p. 100 cholesterol than in the conventional animal (Kellogg and Wostmann, 1969b).

According to Einarsson, Gustafsson and Gustafsson (1973), 7a-hydroxylase activity is higher in the conventional state, and the effect of bacteria may be partly mediated via increased cholesterol $7 \alpha$-hydroxylation in the liver since the activity of this enzyme is supposed to be the rate-limiting step in the conversion of cholesterol into bile acids (Danielssson, Einarsson and Johansson, 1967). However, the data obtained by Ukai, Tomura and to (1976), showing enlarged pools of both cholesterol and bile acids in the enterohepatic circulation of the germ-free rat, suggest that the decrease in hepatic cholesterol catabolism might be due to slower total metabolism in the germ-free animal. 


\section{Other intestinal enzymes}

No difference was found between germ-free and conventional rats as to the patterns of hexokinase, glucose-6-phosphatase, pyruvate kinase and lactate dehydrogenase distribution along the gastrointestinal tract (Kawai and Morotomi, 1978). Neither did these authors find any difference in hexokinase or pyruvate kinase activities in these animals, whereas glucose-6-phosphatase activity in the whole digestive tract and lactate dehydrogenase activity in the cecum were higher in the germ-free rats.

Histochemical studies in the mouse do not show any significant differences between germ-free, monocontaminated and conventional animals as to the duodenal and jejunal enzyme activity of NAD and NADP succinic dehydrogenase and esterase (Herskovic et al., 1967). The activity of alkaline-phosphatase and adenosine-triphosphatase, which are involved in active intestinal transport systems, is higher in the germfree mouse (Jervis and Biggers, 1964) and rat (Reddy, 1971 ; Kawai and Morotomi, 1978) than in their conventional counterparts. Acid phosphatase, involved in local defense mechanisms, has a lower activity in the germ-free than in the conventional mouse (Jervis and Biggers, 1964).

\section{Conclusions.}

Some general conclusions may be drawn from the above analysis. Firstly, data on digestive enzymes do not actually provide a complete picture of digestive enzyme equipment in the germ-free animal. Indeed, information on salivary amylase is scarce, and we have no data on gastric proteolytic enzymes and intestinal peptidases.

Secondly, taking into account what we know, i.e. pancreatic enzymes and intestinal disaccharidases, it can be concluded that the digestive enzyme equipment of the germ-free is similar to that described in its conventional counterpart. Even if they are not directly related to enzymes, the bile salts secreted in bile are qualitatively and quantitatively different in germ-free and conventional states. Nevertheless, it is not clear if such differences could affect the process of dietary lipid hydrolysis by pancreatic lipase in the germ-free.

Finally, most authors agree that enzyme activity in the distal part of the digestive tract is higher in the germ-free than in the conventional animal. In the latter, endogenous enzyme secretions are inactivated by bacteria at that level, indicating the presence of a greater amount of endogenous matter in the intestinal lumen of the germ-free animal, as shown by some authors. Combe et al. (1965), Reddy, Pleasants and Wostmann (1969), Combe, Arnal and Sacquet (1967) and Loesche (1968) studying the rat, Loesche (1968) and Whitt and Demoss (1975) the mouse, and Salter and Coates (1971) the chicken, reported a large accumulation of endogenous proteins and free amino acids in the germ-free state. The nature of the nitrogen present in the cecum differs in germ-free and conventional animals. In the former, it is mainly represented by endogenous proteins : enzymes, mucoproteins, desquamated cells, more of less longchain peptides and free amino acids. In the conventional animal, the cecal nitrogenous material (dietary residues, microorganisms and lesser amounts of endogenous proteins) is primarily undigested and unabsorbed. The accumulation of nitrogenous material and water in the cecum of germ-free animals is in part due to the fact that their 
cecal absorption is inhibited (Combe and Gordon, 1969 ; Loeschke and Gordon, 1970), whereas the excretion of plasma proteins is similar in germ-free and conventional rats (Levenson, Gruber and Kan, 1969). Accumulation of carbohydrates was also reported in the cecum of germ-free animals. The cecal contents of germ-free rats and mice are higher (20 to $200 \mathrm{p}$. 100) in soluble carbohydrates than those of conventional animals. The soluble carbohydrate level is 150 p. 100 higher in the fowl cecum 8. hrs after the beginning of the meal (Szylit, 1971). This cannot be explained by a decrease in amylase activity in the germ-free, but rather by the fact that starch is degraded more rapidly when the grains are surrounded by live bacteria (Baker ef al., 1950). Although it is beyond the scope of this review, a general look at the processes of digestion in the germ-free animal is informative. Three main factors are involved: (i) gastrointestinal transit determining the distribution of dietary substrates in the different parts of the intestine, (ii) gastrointestinal enzymes acting on the dietary substrates and contributing to the release of products which are submitted to (iii) absorption. Gastrointestinal transit is slower in germ-free than in conventional animals; thus, it can be assumed that intestinal enzyme digestion is more efficient in the germ-free since enzyme contact with the dietary substrate is more durable and it has been shown that enzyme activity remains high in the distal gut contents. The absorption of enzyme hydrolytic products is generally higher in the germ-free than in the conventional animal. According to Whitt and Demoss (1975), the lower free amino acid concentrations in the distal part of the germ-free small intestine reflects the greater absorption rate of those products. The absorption of ${ }^{14} \mathrm{C}$-L-methionine is twofold higher in the germ-free than in the conventional mouse (Herskovic ef al., 1967), whereas Riedel, Scharrer and Lösch (1972) showed very little difference in the intestinal absorption of ${ }^{14} \mathrm{C}$-leucine in germ-free and conventional fowl. Xylose absorption is twice as quick in the germfree rat and mouse as in their conventional counterparts (Heneghan, 1963). Lipid absorption depends on the type of fat ingested ; saturated fatty acids, such as palmitic and stearic acids, are better absorbed in the germ-free than in the conventional rat (Demarne ef al., 1970).

In theory, the germ-free animal possesses a whole set of physiological characteristics allowing a better digestive utilization of the diet ingested. The measurement of apparent digestibility is a criterion commonly used to estimate the digestive utilization of the diet. The results obtained on germ-free and conventional animals are contradictory. Apparent nitrogen digestibility may be higher (Yoshida ef al., 1968 ; Yamanaka et al., 1972) or lower (Combe, 1971 ; Corring, Moreau and Ducluzeau, 1979) in the germ-free than in the conventional animal. Coates, Hewitt and Salter (1973) did not find any difference in the apparent nitrogen digestibilities of germ-free and conventional chickens. Apparent digestibility of nitrogen-free extract decreases from 80 to 66 p. 100 in the rabbit without flora (Yoshida et al., 1968). In the absence of microflora, apparent lipid digestibility (Luckey, 1963 ; Yamanaka et al., 1972), particularly that of long-chain saiurated fatty acids (Boyd and Edwards, 1967 ; Demarne et al., 1970, 1972), is higher. The reasons for such a discrepancy in these results have not been fully understood. However, it seems likely that the microflora may play a role in the digestive utilization of the diet in the conventional animal. The amounts and types of digestive residues, coming from the small bowel and passing through the ileo-cecal valve into the distal digestive tract, may vary according to the nature of the dietary compo- 
nents (Rérat, 1978). In the germ-free animal, these residues, augmented by endogenous secretions, would be found in the feces and thus change the apparent digestibility of the diet. In the conventional animal, the microflora may reduce apparent nitrogen digestibility as, for instance, when fecal exogenous nitrogen excretion is low, and increase that digestibility when the supplies of undigested amino acids are high (Rérat, 1978). The experiments of Corring, Moreau and Ducluzeau (1979) confirm the latter point. Indeed, in conventional rats, the nitrogen digestibility of a semi-purified diet is only slightly (but significantly) reduced by suppression of pancreatic secretion. In contrast, nitrogen digestibility is definitively decreased by pancreatic deviation in germ-free rats. It would thus seem that the presence of microflora leads to an improvement of nitrogen digestibility.

Reçu en juillet 1980.

Accepté en jonvier 1981.

Résumé. L'animal germ-free présente un certain nombre de caractéristiques dans sa physiologie digestive qui le différencient de son homologue conventionnel : hypertrophie du cæcum, ralentissement du renouvellement cellulaire dans l'intestin grêle, ralentissement de l'évacuation gastrique et du transit intestinal. Afin de compléter l'étude de ces caractéristiques, essentielle si l'on veut utiliser l'animal germ-free pour préciser le rôle de la microflore gastrointestinale dans la nutrition du conventionnel, un ensemble de données relatives aux enzymes digestives chez le germ-free sont analysées dans cette revue.

II apparaît que les informations sont rares en ce qui concerne l'amylase salivaire et inexistantes pour ce qui est des enzymes protéolytiques gastriques et des peptidases intestinales. Plus nombreuses en ce qui concerne les enzymes du pancréas exocrine ef les disaccharidases intestinales, elles montrent que l'équipement enzymatique digestif de l'animal germ-free est semblable à celui de l'animal conventionnel. Les sels biliaires, non considérés comme enzymes digestives sont, qualitativement et quantitativement différents en fonction de l'environnement bactérien du tube digestif.

Si l'on reprend les principaux aspects de la physiologie digestive, l'animal germ-free présente un certain nombre de caractéristiques qui devraient lui permettre de mieux utiliser l'aliment ingéré. Les mesures de digestibilité apparente ne permettent pas de valider cette hypothèse puisque chez une même espèce les résultats obtenus chez l'animal germ-free et son homologue conventionnel sont contradictoires.

\section{References}

ABRAMS G. D., BAUER H., SPRINZ H., 1963. Influence of the normal flora on mucosal morphology and cellular renewal in the ileum. A comparison of germ-free and conventional mice. Lab. Invest., 12, 355-364.

ABRAMS G. D., BISHOP J. E., 1967. Effect of the normal microflora on gastro-intestinal motility. Proc. Soc. exp. Biol. Med., 126, 301-304.

ARIES V., HILL M. J., 1970a. Degradation of steroids by intestinal bacteria. I. Deconjugation of bile salts. Biochim. biophys. Acta, 202, 526-534.

ARIES V., HILL M. J., 1970b. Degradation of steroids by intestinal bacteria. II. Enzymes catalyzing the oxido-reduction of the $3 \alpha, 7 \alpha$ and $12 \alpha$-hydroxy group in cholic acid and the dehydroxylation of 7-hydroxyl group. Biochim. biophys. Acia, 202, 535-543.

ARIES V., HILL M. J., 1970c. The formation of unsaturated bile acids by intestinal bacteria. Biochem. J., $119,37$.

BAKER F., NASR H., MORRICE F., BRUCE J., 1950. Bacterial breakdown of structural starch products in the digestive tract of ruminant and non-ruminant mammals. J. Path. Bact., 52, 617-638.

BEWA H., CHARLET-LERY G., SZYLIT O., 1979. Rôle de la microflore digestive et de la structure cristalline de l'amidon dans la digestion ef l'utilisation des régimes chez le poulet. Etude des tubercules tropicaux. Ann. Nutr. Aliment., 33, 213-231. 
BORGSTRÖM B., DAHLQVIST A., GUSTAFSSON B. E., LUNDH G., MALMQUIST J., 1959. Trypsin, invertase and amylase content of feces of germ-free rats. Proc. Soc. exp. Biol. Med., 102, 154-155,

BOYD G. S., EDWARDS H. M., 1967. Fat absorption by germ-free chicks. Poultry Sci., 46, 1481-1483.

COATES M. E., HEWITT S., GOLOB P., 1970. A comparison of the effects of raw and heated soyabean meal in diets for germ-free and conventional chicks. Br. J. Nutr., 24, 213-225.

COATES M. E., HEWITT D., SALTER D. N., 1973. Protein metabolism in the germ-free and conventional chick, 291-295. In J. B. HENEGHAN, Germ-free research. Biological effect of gnotobiofic environments. Acad. Press, New York and London.

COMBE E., 1971. Etude de l'azote endogène dans le contenu digestif des rats holoxéniques et axéniques à l'aide d'acides aminés ${ }^{14} \mathrm{C}$. C. R. Soc. Biol., 165, 289-295.

COMBE E., ARNAL M., SACQUET E., 1967. Etude à l'aide d'acides aminés marqués de l'origine des composés azotés contenus dans le cæcum des rats axéniques. C. R. Soc. Biol., 161, 1076-1079.

COMBE E., DEMARNE Y., GUÉGUEN L., IVOREC-SZYLIT O., MESLIN J. C., SACQUET E., 1976. Some aspects of the relationship between gastrointestinal flora and host nutrition. WId. Rev. Nutr. Diet., 24, 1-57.

COMBE E., GORDON H. A., 1969. Bidirectional permeation of water and amino acids in the cecum of germ-free rats, 169-170. In E. MIRAND, Germ-free biology, Plenum Publ. Co., New York.

COMBE E., PENOT E., CHARLIER H., SACQUET E., 1965. Métabolisme du rat « germ-free ». Teneur des contenus digestifs en certains composés azotés, en sodium, en potassium. Teneurs de quelques tissus en acides nucléiques. Ann. Biol. anim. Bioch. Biophys., 5, 189-206.

CORRING T., MOREAU C., DUCLUZEAU R., 1979. Comparative apparent digestibility of casein in holoxenic, axenic and Clostridium bifermantans monoassociated rats. Am. J. clin. Nutr., 32, $1231-1237$.

DAHLQVIST A., 1963. Rat intestinal dextranase. Localization and relation to the other carbohydrases of the digestive tract. Biochem. J., 86, 72-76.

DAHLQVIST A., BORGSTRÖM B., 1961. Digestion and absorption of disaccharides in man. Biochem. J., 81, 411-418.

DAHLQVIST A., BULL B., GUSTAFSSON B. E., 1965. Rat intestinal 6-bromo-2-naphtyl glycosidase and disaccharidase activities. Enzymatic properties and distribution in the digestive tract of conventional and germ-free animals. Arch. Biochem. Biophys., 109, 150-158.

DAHLQVIST A., THOMSON D. L., 1964. The digestion and absorption of lactose by the intact rat. Acfa physiol. scand., 61, 20-33.

DANIELSSON H., EINARSSON K., JOHANSSON G., 1967. Effect of biliary drainage on individual reaction in the conversion of cholesterol to taurocholic acid. Eur. J. Biochem., 2, 44-49.

DEMARNE Y., SACQUET E., FLANZY J., GARNIER H., FRANÇOIS A. C., 1970. Utilisation digestive apparente des acides gras chez le rat axénique et le rat holoxénique. Ann. Biol. anim. Bioch. Biophys., 10, 369-384.

DEMARNE Y., SACQUET E., FLANZY Y., GARNIER H., 1972. Influences cumulées de la cæcectomie et de l'état axénique sur l'utilisation digestive apparente de la ration et des acides gras chez le rat. Ann. Biol. anim. Bioch. Biophys., 12, 139-148.

DEMARNE Y., SACQUET E., GARNIER H., 1972. La flore gastrointestinale et la digestion des matières grasses chez le monogastrique. Ann. Biol. anim. Bioch. Biophys., 12, 509-524.

DUCLUZEAU R., RAIBAUD P., 1975. La flore microbienne du tube digestif chez le monogastrique et son influence sur les métabolismes nutritionnels de l'hôte. $Z$. Ernährugswiss., 14, 133-144.

ECKNAUER R., RAFFLER H., 1978. Effect of starvation on small intestinal enzyme activity in germfree rats. Digestion, 18, 45-55.

EINARSSON K., GUSTAFSSON J. A., GUSTAFSSON B. E., 1973. Differences between germ-free and conventional rats in liver microsomal metabolism of steroids. J. biol. Chem., 248, 3623-3630.

EYSSEN H. J., PARMENTIER G. G., MERTENS J., 1976. Sulfated bile acids in germ-free and conventional mice. Eur. J. Biochem., 66, 507-514.

GEEVER E. F., DAFT F. S., LEVENSON S. M., 1965. Pancreatic atrophy and fibrosis in the germ-free rat on a chemically defined diet. Fed. Proc., 24, 246 (abstr.).

GENELL S., GUSTAFSSON B. E., OHLSSON K., 1976. Quantitation of active pancreatic endopeptidases in intestinal contents of germ-free and conventional rats. Scand. J. Gostroenterology, 11, 757-762. 
GLIMSTEDT G., 1936. Bakłerienfreie Meerschweinchen-Aufzucht Lebensfähigkeit und Wachstum, nebs untersuchungen über das Lyphatische Gewebe. Acta path. microbiol. scand., suppl., 30, 1-295.

GORDON H. A., BRUCKNER-KARDOSS E., 1961. Effect of normal flora on intestinal surface area. Am. J. Physiol., 201, 175-178.

GORDON H. A., BRUCKNER-KARDOSS E., STALEY T. E., WAGNER M., WOSTMANN B. S., 1966. Characteristics of the germ-free rat. Acta anat., 64, 367-389.

GORDON H. A., WOSTMANN B. S., 1960. Morphological studies on the germ-free albino rat. Anat. Rec., 137, 65-70.

GRAY G. M., COOPER H. L., 1971. Protein digestion and absorption. Gastroenterology, 61, 535-544.

GUENET J. L., SACQUET E., GUENEAU G., MESLIN J. C., 1970. Action de la microflore totale du rat sur l'activité mifotique des cryptes de Lieberkühn. C. R. Acad. Sci. Paris, sér. D, 270, 3087-3090.

HEIZER W. D., KERLEY R. L., ISSELBACHER K. J., 1972. Intestinal peptide hydrolases differences between brush-border and cytoplasmic enzymes. Biochim. biophys. Acta, 264, 450-461.

HENEGHAN J. B., 1963. Influence of microbial flora on xylose absorption in rats and mice. Am. J. Physiol., 205, 417-420.

HERSKOVIC T., KATZ J., FLOCH M. H., SPENCER R. P., SPIRO H. M., 1967. Small intestinal absorption and morphology in germ-free, monocontaminated, and conventionalized mice. Gastroenterology, 52, 1136.

HOFMANN A. F., MOSBACH E. H., SWEELEY C. C., 1964. Bile acid composition from germ-free rabbits. Biochim. biophys. Acta, 176, 204-207.

IVOREC-SZYLIT O., RAIBAUD P., SCHELLENBERG P., 1973. The breakdown of starch at different levels in the digestive tract of the axenic, gnotoxenic and holoxenic chicken, 225-231. In J. B. HENEGHAN, Germ-free reseorch. Acad. Press, New York and London.

JERVIS H. R., BIGGERS D. C., 1964. Mucosal enzymes in the cecum of conventional and germ-free mice. Anat. Rec., 148, 591-595.

KAWAI Y., MOROTOMI M., 1978. Infestinal enzyme activities in germ-free, conventional and gnotobiotic rats associated with indigenous microorganisms. Infect. Immun., 19, 771-778.

KELLOGG T. F., 1971. Microbiological aspects of enterohepatic neutral sterol and bile acid metabolism. Fed. Proc., 30, 1808-1814.

KELLOGG T. F., WOSTMANN B. S., 1969a. Fecal neutral steroids and bile acids from germ-free rats. J. Lipid Res., 10, 495-503.

KELLOGG T. F., WOSTMANN B. S., 1969b. The response of germ-free rats to dietary cholesterol, 293-295. In E. MIRAND, Germ-free biology. Plenum Publ. Co., New York.

KWONG E., GRUBER C., KAN D., BARNES R. H., LEVENSON S. M., 1971. Effect of soyabean trypsin inhibitor upon pancreatic cystine synthesis in germ-free rats. Fed. Proc., 30, 641 (abstr.).

LARNER J., GILLEPSIE R. E., 1957. Gastrointestinal digestion of starch. III. Intestinal carbohydrase activities in germ-free and non-germ-free animals. J. biol. Chem., 225, 278-285.

LEE H. W., MOINUDDIN J. F., 1958 . Effects of oral tetracycline on diarrhea and on the dry weights of cleaned organs in rats fed two different diets. Am. J. Physiol., 192, 421-426.

LEPKOVSKY S., WAGNER M., FURUTA F., OZONE K., KOIKE T., 1964. The proteases, amylase and lipase of the intestinal contents of germ-free and conventional chickens. Poultry Sci., 43, 722726.

LEPKOVSKY S., FURUTA F., OZONE K., KOIKE T., 1966. The proteases, amylase and lipase of the pancreas and intestinal contents of germ-free and conventional rats. Br. J. Nutr., 20, 257-261.

LESHER S., WALBURG Jr. H. E., SACHER Jr G. A., 1964. Generation cycle on the duodenum crypt cells of germ-free and conventional mice. Nature, 202, 884-885.

LEVENSON S. M., GRUBER C., KAN D., 1969. Similarity in passage rates of plasma proteins into the gut of germ-free and conventionalized rats. J. Nutr., 98, 99-104.

LOESCHE W. J., 1968 . Protein and carbohydrate composition of cecal contents of gnotobiotic rats and mice. Proc. Soc. exp. Biol. Med., 128, 195-199.

LOESCHKE K., GORDON H. A., 1970. Water movement across the cecal wall of the germ-free rat. Proc. Soc. exp. Biol. Med., 133, 1217-1222.

LUCKEY T. D., 1963. Germ-free life and gnotobiology, Acad. Press, New York, London, p. 252. 
MALIS F., FRIC P., LOJDA Z., STEPANKOVA R., KRUML J., 1974. Verdanungsenzyme des Dünndarms und Pankreas bein Keimfreien Tieren. Dent. Zeit. Verdan. Stoffweckselkr., 34, 225-228.

MALIS F., FRIC P., STEPANKOVA R., KRUML J., 1976. Trypsin and chymotrypsin activity of the intestinal confent in germ-free, monoassociated and conventional rabbits. Physiol. Bohemoslov, 25, 71-74.

MASSON M. J., 1954. Microscopic studies of the gut flora of hen with special reference to the breakdown of starches. Proc. 10th WId Poultry Congr., 105-141.

MAYLIE M. F., CHARLES M., GACHE C., DESNUELLE P., 1971. Isolation and partial identification of a pancreatic colipase. Biochim. biophys. Acto, 229, 286-289.

MESLIN J. C., 1971. Action de la microflore totale du rat sur l'épithélium intestinal. Estimation de la surface absorbante. Ann. Biol. anim. Bioch. Biophys., 11, 334-335.

MESLIN J. C., SACQUET E., GUENET J. L., 1973. Action de la flore bactérienne sur la morphologie et la surface de la muqueuse de l'intestin grêle du rat. Ann. Biol. onim. Bioch. Biophys., 13, $203-$ 214.

MESLIN J. C., SACQUET E., RAIBAUD P., 1974. Action d'une flore microbienne qui ne déconjugue pas les sels biliaires sur la morphologie ef le renouvellement cellulaire de la muqueuse de l'intestin grêle du rat. Ann. Biol. onim. Bioch. Biophys., 14, 709-720.

MEYNELL G. G., 1963. Antibacterial mechanism of the mouse gut. II. The role of Eh and volatile fatty acids in the normal gut. Br. J. exp. Path., 44, 209-219.

PHILIPS B. P., WOLFE P. A., GORDON H. A., 1959. Studies on rearing the germ-free guinea pig. Ann. N. Y. Acad. Sci., 78, 183-207.

PLEASANTS J. R., 1959. Rearing germ-free caesarian-born rats, mice and rabbits through weaning. Ann. N. Y. Acad. Sci., 78, 116-126.

REDDY B. S., 1971. Calcium and magnesium absorption. Role of intestinal microflora. Fed. Proc. Fed. am. Soc. exp. Biol., 30, 1815-1821.

REDDY B. S., PLEASANTS J. R., WOSTMANN B. S., 1968. Effect of dietary carbohydrates on intestinal disaccharidases in germ-free and conventional rats. J. Nutr., 95, 413-419.

REDDY B. S., PLEASANTS J. R., WOSTMANN B. S., 1969. Pancreatic enzymes in germ-free and conventional rats fed chemically defined, water-soluble diet free from natural substrates. $J$. Nutr., 97, 327-334.

REDDY B. S., WOSTMANN B. S., 1966. Intestinal disaccharidase activities in the growing germ-free and conventional rats. Arch. Biochem. Biophys., 113, 609-616.

RÉRAT A., 1978. Digestion and absorption of carbohydrates and nitrogenous matters in the hindgut of the omnivorous non-ruminant animal. J. onim. Sci., 46, 1808-1837.

RIEDEL G., SCHARRER E., LÖSCH U., 1972. Resorptionstudien an Keimfreien Küken. I. Aminosaürenresorption. Zbl. Vet. Med., 19, 563-568.

RIOTTOT M., SACQUET E., VILA J. P., LEPRINCE C., 1980. Relationship between small intestine transit and bile acid metabolism in axenic and holoxenic rats fed different diets. Reprod. Nutr. Dévelop., 20, 163-171.

ROLLS B. A., TURVEY A., COATES M. E., 1978. The influence of the gut microflora and of dietary fibre on epithelial cell migration in the chick intestine. Br. J. Nutr., 39, 91-98.

ROZÉ C., SACQUET E., CHARIOT J., DUBRASQUET M., ACCARY J. P., 1977. Quelques caractéristiques des sécrétions pancréatique ef gastrique chez le rat axénique. Forum de Gastroentérologie, Paris.

SACQUET E., 1971. Flore microbienne du tractus digestif et nutrition chez Ratfus norvegicus. Thèse Doct. Sci, , Paris.

SACQUET E., GARNIER H., RAIBAUD P., 1970. Etude de la vitesse du transit gastro-intestinal des spores d'une souche thermophile stricte de Bacillus subtilis chez le rat « holoxénique », le rat « axénique » ef le rat " axénique » cæecectomisé. C. R. Soc. Biol., 164, 532-537.

SACQUET E., VAN HEIJENOORT Y., RIOTTOT M., LEPRINCE C., 1975. Action de la flore microbienne du tractus digestif sur le métabolisme des acides biliaires chez le rat. Biochim. biophys. Acto, 380, 52-65.

SACQUET E., MEJEAN C., LEPRINCE C., RIOTTOT M., RAIBAUD P., 1976. Action du régime alimentaire et de la flore microbienne du tractus digestif sur le pool intestinal et l'excrétion fécale des acides biliaires chez le rat : étude comparée chez des rats axéniques, gnotoxéniques et holoxéniques. Ann. Nutr. Alim., 30, 603-617. 
SACQUET E., LEPRINCE C., RIOTTOT M., 1979. Effect of different modifications of a semi-synthetic diet on bile acid metabolism in axenic and holoxenic rats. Ann. Biol. onim. Bioch. Biophys., 19, 1677-1688.

SALTER D. N., COATES M. E., 1971. The influence of the microflora of the alimentary tract on protein digestion in the chicks. Br. J. Nutr., 26, 55-69.

SAVAGE D. C., SCHAEDLER R. W., DUBOS R. J., 1967. Effects of bacteria on gastrointestinal histology. Fed. Proc., 26, 803 (abstr.).

SCHAEDLER R. W., 1973. The relationship between the host and its intestinal flora. Proc. Nutr. Soc. 32, 41-47.

SCHIFF E. R., SMALL N. C., DIETSCHY J. M., 1972. Characterization of the kinetics of the passive and active transport mechanisms for bile acid absorption in the small intestine and colon of the rat. J. clin. Invest., 51, 1351-1362.

SEIJFFERS M. J., SEGAL H. L., MILLER L. L., 1963. Separation of pepsinogen I, pepsinogen II and pepsinogen III from human gastric mucosa. Am. J. Physiol., 20, 1106-1116.

SIDDONS R. C., 1969. Intestinal disaccharidase activities in the chick. Biochem. J., 112, 51-59.

SIDDONS R. C., COATES M. E., 1972. The influence of the intestinal microflora on disaccharidase activities in the chick. Br. J. Nutr., 27, 101-112.

SPRINZ H., KUNDEL D. W., DAMMIN G. J., HOROWITZ R. E., SCHNEIDER H., FORMAL S. B., 1961. The response of the germ-free guinea pig to oral bacteria challenge with Escherichia coli and Shigella flexneri : with special reference to lymphatic tissue and the intestinal tract. Am. J. Path., $39,681-695$.

SZYLIT O.,1971. Ełude comparée de la dégradation de l'amidon dans les cæca du poulet axénique et orthoxénique. C. R. Acod. Sci. Paris, sér. D, 273, 1132-1135.

SZYLIT O., 1973. Les voies métaboliques de la dégradation de l'amidon dans le jabof de Gallus gallus et leurs incidences nutritionnelles. Thèse Doct. Sci., Paris.

THORBECKE G. J., GORDON H. A., WOSTMANN B. S., WAGNER M., REYNIERS J. A., 1957. Lymphoïd tissue and serum gamma globulin in young germ-free chickens. J. Infect. Dis., 101, 237. 251.

UKAI M., TOMURA A., ITO M., 1976. Cholesterol synthesis in germ-free and conventional rats. J. Nutr., 106, 1175-1183.

WHITT D. D., DEMOSS R. D., 1975. Effect of microflora on the free amino acid distribution in various regions of the mouse gastrointestinal tract. Appl. Microbiol., 30, 609-615.

WOSTMANN B. S., 1973. Intestinal bile acids and cholesterol absorption in the germ-free rat. J. Nutr., 103, 982-990.

WOSTMANN B. S., BRUCKNER-KARDOSS E., 1959. Development of cecal distention in germ-free baby rats. Am. J. Physiol., 197, 1345-1346.

WOSTMANN B. S., BRUCKNER-KARDOSS E., KNIGHT Jr P. L., 1968. Cecal enlargement, cardiac output, and $\mathrm{O}_{2}$ consumption in germ-free rats. Proc. Soc. exp. Biol. Med., 128, 137-141.

WOSTMANN B. S., BRUCKNER-KARDOSS E., BEAVER M., CHANG L., MADSEN D., 1976. Effect of diefary lactose at levels comparable to human consumption on cholesterol and bile acid metabolism of conventional and germ-free rats. J. Nutr., 106, 1782-1790.

YAMANAKA M., IWAI H., SAITO M., YAMAUCHI C., NOMURA T., 1972. Influence of intestinal microbes on digestion and absorption of nutrients in diet and nitrogen retention in germ-free, gnotobiotic and conventional mice. I. Protein and fat digestion and nitrogen retention in germfree and conventional mice. Jap. J. Zootech. Sci., 43, 272-283.

YOSHIDA T., PLEASANTS J. R., REDDY B. S., WOSTMANN B. S., 1968. Efficiency of digestion in germ-free and conventional rabbits. Br. J. Nutr., 22, 723-737. 